\title{
Inflation, Macroeconomic Policy and Hunger: A Variation on a Theme by C. Rangarajan
}

\author{
Raghbendra Jha,
}

Australia South Asia Research Centre, Arndt-Corden Department of Economics, College of Asia and the Pacific, Australian National University, Canberra, ACT 0200, Australia Phone: + 61261252683

Fax: +61261250443

Email: r.jha@anu.edu.au 


\begin{abstract}
This paper re-emphasizes the importance of price stability as a tool for macroeconomic policy and make it more specific by considering a typically (unanticipated) advantage of stabilizing the Consumer Price Index (CPI). I briefly review the recent economic growth performance of the Indian economy and recount the sluggish response of poverty to high economic growth. Further, hunger (calorie deficiency) has actually increased during the post-reform period. Using household level National Sample Survey (NSS) data for 1993-94 and 2004-05 the paper shows that calorie intakes in both rural and urban areas are sensitive to commodity (in particular foodgrain) prices. Hence, reducing consumer price inflation is likely to yield a rich dividend by reducing hunger. Indeed rising per capita incomes are not likely to be sufficient to reduce hunger. The paper also reviews some policy challenges to stabilizing consumer prices.
\end{abstract}

JEL Codes: D11, E31, E43, I18, I32, O11

Keywords:

Inflation targeting, Consumer Price Index, Hunger, Development Policy, India 
... In just decades, you have achieved progress and development that took other nations centuries. ...

(US President Barack Obama in his address to the Indian Parliament on 8 November 2010)

\section{Introduction}

India's recent economic transformation, particularly since the watershed economic reforms of 1991, has been remarkable. This is only partially reflected in higher trend GDP per capita growth rates, not to speak of the resilience of the economy to the sharpest downturn in worldwide economic activity and trade since the Great Depression, and would need several indicators, in particular those that reflect the quantum leap in opportunities available to common citizens to truly capture the impact of India’s recent economic transformation. When such sustained economic growth occurs in a country of over a billion people, more than half of them under the age of 25 , in a political system of multi-party parliamentary democracy, a federal structure and against the backdrop of widespread poverty the unique nature of such transformation becomes evident. This is indeed unparalleled in human history.

Dr C. Rangarajan's work has been central to India's rapid transformation. His credentials as an academic economist are stellar enough. To top this he has been at the centre of almost every aspect of policy formulation and execution since the early 1990s. To mention just a few - he has been India's central banker, headed the $11^{\text {th }}$ Finance Commission and has been Chairman of the Council of Economic Advisors to the Prime Minister. His work, advice and economic administration have been pivotal to India's recent economic success. Not only has he formulated and guided successful economic policy but has, no doubt, been instrumental in addressing episodes of economic crises. In addition to all this he has been governor of Andhra Pradesh and has served as a nominated member of the Rajya Sabha. This list of accomplishments is no doubt incomplete. Truly it is not possible to imagine India's recent economic success and potential for further growth without acknowledging the contribution of C. Rangarajan.

This paper is written as a tribute to Dr. Rangarajan and goes back to an early theme, curbing inflation, developed by him in his role as India's Central Banker. Although the case for price stability as a macroeconomic goal was always strong, no one in India has done more to move this to centre stage than Dr. Rangarajan. As RBI governor and in a number of publications (e.g. Rangarajan 1997, 2004) he laid out the case for price stability forcefully. 
Whereas the case for price stability as a goal of macroeconomic policy has been considered unexceptionable for some time a strong body of thought has considered some inflation to be conducive for economic growth in the context of an emerging market economy like India. For a good survey of this argument and a survey of the literature see Li (2006).

This contribution uses data for 90 developing countries and 28 developed for the period 1961 to 2004. Li shows that the relationship between inflation and economic growth is nonlinear. For developing countries, including India, the data suggest the presence of two thresholds in the function relating economic growth and inflation. At rate of inflation lower than that of the first threshold, the effects of inflation on growth are insignificant and even positive; at moderate rates of inflation, which are between the two threshold levels, the effects of inflation are significantly and strongly negative; at extremely high rates of inflation, the marginal impact of additional inflation on economic growth diminishes. The first threshold level of inflation is estimated at 14 percent per year, and the second threshold level at 38 percent per year. For developed countries there is a unique threshold (24 per cent). The magnitude of the negative effect of inflation on growth declines as the inflation rate increases.

However, the contributions of $\mathrm{Li}$ and others have one important drawback from the policy perspective. Nowhere is it shown that the inflation levels being considered are sustainable levels of inflation. It is quite likely that even at the (lower) threshold level of inflation for developing countries (14 per cent) expected inflation might be going up in which case actual inflation would be accelerating in the next time period. Hence, we need a measure of nonaccelerating inflation. The proper relation to estimate should be between this measure and economic growth. In other words, we need to estimate a Non-Accelerating Inflation Growth relation (NAIG). To the best of my knowledge there is no work in this area.

Dr Rangarjan would be right to consider a rate of inflation of 14 per cent unacceptable.

In this paper I re-emphasize Rangarajan's view on price stability and make it more specific by considering a typically (unanticipated) advantage of stabilizing the CPI. The plan of this paper is as follows. Section II briefly reviews the recent economic growth performance of the Indian economy and recount the sluggish response of poverty to high economic growth. This section also indicates that hunger (calorie deficiency) has actually increased during the post-reform period. Using household level NSS data for 1993-94 and 2004-05 section III shows that calorie intakes in both rural and urban prices are sensitive to commodity prices. 
Hence, reducing consumer price inflation is likely to yield a rich dividend in lower incidence of hunger. Indeed rising per capita incomes are not likely to be sufficient to reduce hunger. Section IV briefly reviews some policy challenges to stabilizing consumer prices and section $\mathrm{V}$ concludes.

\section{Poverty Reduction, Undernutrition and macroeconomic performance}

As remarked above economic growth has been very robust in India in recent years. Table 1 gives a summary of recent growth performance for the aggregate economy and major sectors. It is clear that the economy has come out of the Global Financial Crisis (GFC) relatively unscathed. Real GDP growth in 2010-11 has been forecasted to be 8.5 per cent and to then approach the previously attained 9 per cent.

\section{Table 1 here}

Even though India's real GDP growth is high ${ }^{1}$ the structural composition of this growth is such that its impact on poverty reduction has been sluggish (Jha, 2004). In fact, as Table 2 indicates the poverty elasticity of India's growth is lower than that of Bangladesh, Vietnam and Sri Lanka.

\section{Table 2 here}

As a consequence poverty reduction in India, despite the high growth rate, has been slow. Based on NSS household level data for the 21 year period from 1983 to 2004-05 Table 3 demonstrates this point. . In the rural sector whereas the severity of poverty (poverty gap and square of poverty gap) has come down quite sharply the headcount ratio has had a modest decline from 46.5 per cent to 28.7 per cent. Also the pace of decline of poverty has come down after the reforms. Whereas the headcount ratio fell by 6.5 percentage points in the four year period between 1983 and 1987-88 it fell only by 8.5 percentage points over the 11 year period 1993-94 to 2004-05. Inequality recorded a modest rise.

In the urban sector the severity of poverty had a more modest decline than in the rural sector. The headcount ratio declined 4.9 percentage points in the four period 1983 to 1987-88 and only by 6.7 percentage points in the post reform 1993-94 to 2004-05 (11 years). Inequality in the urban sector increased sharply. ${ }^{2}$

\footnotetext{
${ }^{1}$ Per capita real GDP growth has, in recent years, been in excess of 7 per cent.

${ }^{2}$ Of course, there are well known spatial differences in poverty attainments across the country, however in this paper I am concentrating on the aggregate picture.
} 


\section{Table 3 here}

The relative disappointment at the poverty impact of the reforms pales into insignificance when one considers progress in reducing hunger over this period. In an influential paper Deaton and Dreze (2009) have shown that average calorie consumption was about 10 percent lower in rural areas in 2004-05 than in 1983. The proportionate decline was larger among the more affluent sections of the population, and negligible for the bottom quartile of Monthly Per Capita Expenditure (MPCE). In urban areas, there was only a slight change in average calorie intake over this period. Proteins and other nutrients declined, but fat increased in both rural and urban areas. ${ }^{3}$

Using NSS household level data for 1993-94 and 2004-05 Gaiha, Jha and Kulkarni (2010a) indicate that if we use the higher calorie requirement ${ }^{4}$ of 2400 , over 71 per cent of the rural households were undernourished in 1993. With the lower intake of 1800, there is a sharp reduction to well below half the proportion (about 31 per cent), implying a large concentration of households in the calorie intake range of 1800-2400. The proportion of undernourished rose from 71 per cent to nearly 80 per cent in 2004. Also, the proportion below the lower cut-off rose from about 31 per cent to close to 37 per cent. By any standard, these imply high incidence of calorie deprivation. What is also significant is that, while the mean calorie intake of those below 1800 rose slightly (from 1491 to 1516), the mean intake of the larger concentration of households in the next higher range (1801-2400) remained about the same. The decline in calorie intake over this period in urban areas was much less severe.

One reason for the deterioration in calorie intake is that both access to and consumption of foodgrain have declined in India in recent times. The latest Economic Survey of the Government of India indicates that foodgrain production in India declined from $208 \mathrm{~kg}$. per annum per capita in 1996-97 to only 186 kg per annum per capita in 2009-10, i.e., a drop of 11 per cent. In addition India has, until recently, been exporting 7 million tonnes of grain

\footnotetext{
${ }^{3}$ Food insecurity and the absence of undernutrition are often used interchangeably in the literature. However, these are distinct concepts, both analytically and operationally. Having enough to eat (food security) is only one facet of having adequate nutrition. The adequacy of nutrition is spelt out in a number of indicators such as the adequate intake of macro nutrients (calorie and protein) and micronutrients (carotene, iron, riboflavin, calcium etc.) and is also expressed in anthropometric terms such as 'right range of BMI' for adults and indicators of stunting and wasting in children. That said, this paper will continue the extant practice of interpreting food insecurity as inadequate consumption of nutrition, in particular calories

${ }^{4}$ Gopalan, Sastri and Balasubramanian (1971) delineate nutritional requirement for different groups of Indians. For adult males doing heavy work in the rural sector the minimum calorie requirement per day is 3900 . Thus 2400 is a relatively modest average.
} 
every year. Higher real incomes lead to lower cereal demand for the rich. But, this is certainly not the case for the poor. Lower cereal demand could be an indicator of distress purchases as food demand is curtailed to enable essential non-food purchases, particularly health and education. Thus, Gaiha, Jha and Kulkarni (2010a) indicate that cereal demand in rural India fell by 9.6 per cent between 1993 and 2004. In urban India the decline was 2.6 per cent. The decline of per capita consumption is not confined to calories. It also applies to proteins and other nutrients, with the exception of fats whose consumption has increased in both rural and urban areas over this period.

Undernutrition apart from being an unwelcome welfare outcome can have serious productivity and labour marker consequences as well. In Jha, Gaiha and Sharma (2009) we test for the existence of a Poverty Nutrition Trap (PNT) in the case of calories and four key micronutrients - carotene, iron, riboflavin, and thiamine — for three categories of wages (sowing, harvesting, and other) and for male and female workers separately. A PNT is said to exist when undernutrition leads to low productivity, hence low wages which then translates to low nutrition, thus completing a vicious cycle.

We conclude that PNT exists in one third (i.e. 10) of the 30 cases. It exists for female harvest wage and female sowing wage for calories. In the case of carotene, male workers engaged in harvesting are subject to the PNT, whereas both male and female workers engaged in harvesting are subject to PNT in the case of iron. In the case of riboflavin female workers engaged in harvesting and sowing and male workers engaged in harvesting are subject to PNT. Since harvesting is physically more demanding than sowing, there is a higher incidence of PNT in harvesting.

Whereas the PNT holds for calories only in the cases of female sowing and female harvesting wages, it holds for males in the case of male harvesting wages (carotene, iron, and riboflavin). For females PNT holds in respect of harvesting and sowing wages for calories, thiamine, and riboflavin, PNT does not exist for females in the case of carotene, and it exists only for harvesting wages in the case of iron. Hence, an analysis which concentrates exclusively on energy intake may present an incomplete picture of the existence of PNT. This analysis shifts the focus to lack of nutritional adequacy as a precondition for participation in labour market activities. Even if some succeed in participating, their wage earnings will not allow them to escape the poverty nutrition trap. Indeed, a mild labour shock (e.g. associated with a crop shortfall) would worsen their plight, as the risk of loss of employment would be considerably 
higher. In particular, female workers are more prone to PNT than male workers, and there is a persistent gender inequality in rural India. We find that improving nutrient intakes can have significant effects on rural wages and, therefore, on the possibility of breaking PNT as well as reducing poverty. Thus public policy should concentrate urgently on providing direct nutritional supplements to the nutritionally deprived in addition to pursuing direct poverty alleviation policies.

\section{Turning Around the Nutrition Shortfall- The Role of Macroeconomic Policy}

Deaton-Dreze (2009) argue that the decline in calorie intake is largely the result of people adopting more sedentary lifestyles as a consequence of economic growth. Hence, their calorie intake requirements may have declined. They claim that this decline is not attributable to changes in relative prices, based on an aggregate measure of the price of food. They argue that there has been a steady downward shift of the calorie Engel curve due to lower calorie 'requirements', mainly with better health and lower activity levels associated with ease of obtaining drinking water, extensive use of bicycles and motor bikes and improved public transportation.

However, this is a proposition to be tested. It may be the case that lower food intake may be a result of higher relative prices of foodgrains, reflecting lower availability (Gaiha et al. 2010b). This also exacerbates the extent of undernourishment. In Tables 4 and 5 I report results on estimates of calorie demand functions for rural and urban India using household data for 1993-94 and 2004-05. The analysis here uses unit as opposed to aggregate prices with the former being calculated as expenditure on a commodity divided by quantity. Both estimates are quite robust and show substantive and significant negative price effects.

Tables 4 and 5 therefore provide an alternative explanation (complementary to that of Deaton and Dreze, 2009) of changes in the consumption of calories over the period, 1993-2004. This explanation is embedded in a standard demand theory framework, with food prices and expenditure (as a proxy for income) cast in a pivotal role. Based on different experiments, robust demand functions are estimated. Our results show consistently robust food price and expenditure effects. Besides, shifts in food price elasticities over time are significant. Over and above these effects, there are shifts in demands due to factors other than those specified in the demand equations. In the context of calories, for example, it is plausible that part of the reduction in their consumption was due to health improvements and less strenuous activity levels - especially but not necessarily confined to rural areas. 
Hence, while the Deaton-Dreze (2009) explanation is not rejected, it is arguable that it is complementary to the demand-based explanations.

From the macroeconomic policy point of view the implication is that for poverty reduction merely expanding incomes will not do. It is important to stabilize prices, particularly consumer prices. This conclusion reasserts the case for inflation stabilization as a key goal of macroeconomic policy in India. It sharpens this case by showing that stabilizing the CPI is important for its own sake. Not only does it help control inflation defined more generally but it also yields rich dividends in the sense of reducing the incidence of hunger. Jha, Bhattacharyya, and Gaiha (2010a) show that the nutritional dividends from such intervention can be quite high even at modest real income transfer per household (roughly equal to one days’ wages for one person per household per month) through the Public Distribution System.

\section{Some difficulties in Stabilizing the CPI in India}

In India price stabilization measures, such as offloading of stocks of foodgrains into some retail markets, may not easily and speedily percolate through to the rest of the country. The most important reason for this is the incomplete integration of agricultural markets so that market shocks/price stabilization measures have imperfect flowthrough (Jha et al., 2006). For instance, the Government of India's Ministry of Labour, Labour Bureaus estimates that while the average monthly price of rice in the country in October 2009 was recorded as Rs20.56 per kilogram, the price across 78 consumption centers ranged from Rs10.34 to Rs30.55. Figure 1 traces the mean, standard deviation and coefficient of variation of wholesale monthly rice prices in 70 centres from 1970:1 to 1999:12. Over this time period the (unit free) coefficient of variation doubled, indicating increase in dispersion over time.

\section{Figure 1 here}

India's archaic system of regulations on foodgrain markets (both wholesale and retail) needs to be urgently reformed to facilitate more effective internal trade (Kumar, Roy and Gulati 2010). Operations such as those of the Food Corporation of India (FCI) are quite inefficient. Kumar et al. (2010) report that the marketing costs of private traders is only about 70 per cent of the costs of the FCI. Further there have been issues relating to procurement, storage and distribution of foodgrain in FCI godowns. In recent times large quantities of grain have decayed in FCI godowns. Jha, Gaiha and Pandey (2010b) show that large scale leakage from the Public Distribution System (PDS) implies that real income transfers through the PDS are meagre. 
An upshot of the argument here is that supply side policies are an indispensable tool in combating consumer price inflation and over emphasis on demand side measures as exercised by monetary policy should be eschewed. ${ }^{5}$ In any case the response of CPI to a change in an interest rate measure such as the call money rate impact effect of an interest measure such as the call money rate on CPI is subject to a wide and rapidly growing band of response. One cannot be certain that a rise in interest rates will have a predictable and stable impact on the CPI (Jha, 2008).

\section{Conclusions}

This paper has argued that reducing inflation should continue to be the cornerstone of macroeconomic policy in India. However, this policy should be more nuanced. In particular, careful attention needs to be paid to stabilizing food prices, especially since this is likely to lead to the additional dividend of lowering hunger.

This paper has also highlighted the role of supply side some structural factors in managing CPI. It has also indicated that there are some structural impediments to good supply side management which need to be removed. In the intermediate run additional policies designed to decisively augment investment and productivity in Indian agriculture need to be put into place. Needless to say, Dr Rangarajan will be at the forefront of such efforts. It is an honor and a privilege to pay tribute to his work.

\footnotetext{
${ }^{5}$ In fact if inflation is initiated by supply side factors such as a drought, as is the case with the inflation of 200910 , supply shocks will reverberate through the economy. The inflation following from these supply shocks will lead to a rise in expected inflation which, in itself, affects aggregate supply adversely. The higher the rate of expected inflation, the lower will be the gap between actual and expected inflation and the smaller the resulting (positive) deviation of output from the trend. Merely reducing demand against the background of recurring adverse supply shocks will, other things remaining unchanged, only lower output growth without having a substantial impact on inflation. The bottom line is that without tackling supply side constraints, there can be no easy victory in the fight against inflation.
} 


\section{References}

Deaton, A. and J. Dreze (2009) ‘Food and Nutrition in India: Facts and Interpretation’, Economic and Political Weekly, 44(7), 42-64.

Gaiha, R., Jha, R. and V. Kulkarni (2010a) ‘Prices, Expenditure and Nutrition in India’ Working Paper 2010/15, Australia South Asia Research Centre, Australian National University, Canberra.

Gaiha, R., Jha, R. and V. Kulkarni (2010b) ‘Demand for Nutrients in India, 1993-2004’, Working Paper 2010/16, Australia South Asia Research Centre, Australian National University, Canberra.

Gopalan, C., B. Sastri, and S. Balasubramanian (1971) Nutritive Value of Indian Foods, National Institute of Nutrition: Indian Council of Medical Research: Hyderabad.

Himanshu (2007) 'Recent Trends in Poverty and Inequality: Some preliminary results', Economic and Political Weekly, 42(6), 497-508, 10 February.

Jha, R. (2004) 'Reducing Poverty and Inequality in India: Has Liberalization Helped', in A. Cornia (ed.) Inequality, Growth and Poverty in an Era of Liberalization and Globalization, New York: Oxford University Press.

Jha, R. (2008) 'Inflation Targeting in India: Issues and Prospects', International Review of Applied Economics, 22(2), pp 259-70.

Jha, R., Murthy, K.V.B and A. Sharma (2006) 'Market Integration in Wholesale Rice Markets in India’ Economic and Political Weekly, 40(53), 5571-7.

Jha, R., Gaiha, R. and A. Sharma (2009) 'Calorie and Micronutrient Deprivation and Poverty Nutrition Traps in Rural India’, World Development, 37(5), 982-91.

Jha, R., Bhattacharyya, S., and R.Gaiha (2010a) 'Social Safety Nets and Nutrient Deprivation: An Analysis of the National Rural Employment Guarantee Program and the Public Distribution System in India’, Working Paper 2010/4, Australia South Asia Research Centre, Australian National University, Canberra.

Jha, R., Gaiha, R. and M. Pandey (2010b) ‘Food Price Subsidy under Public Distribution System in Andhra Pradesh, Maharashtra and Rajasthan', Working Paper 2010/7, Australia South Asia Research Centre, Australian National University, Canberra.

Kumar, G., Roy, D. and A. Gulati (2010) 'Liberalizing Foodgrains Markets: Experiences, Impact and Lessons from South Asia', IFPRI Issue Brief 64, August.

Li, M. (2006) 'Inflation and Economic Growth: Threshold Effects and Transmission Mechanisms', Department of Economics, University of Alberta, mimeo.

Rangarjan, C. (1997) 'Mr Rangarajan examines the objective of monetary policy and price stability in relation to the economy of India', BIS Review, vol. 8. Available at http://www.bis.org/review/r970203b.pdf (Accessed 11th November 2010).

Rangarajan, C. (2004) Select Essays on the Indian Economy, New Delhi: Academic Foundation. 


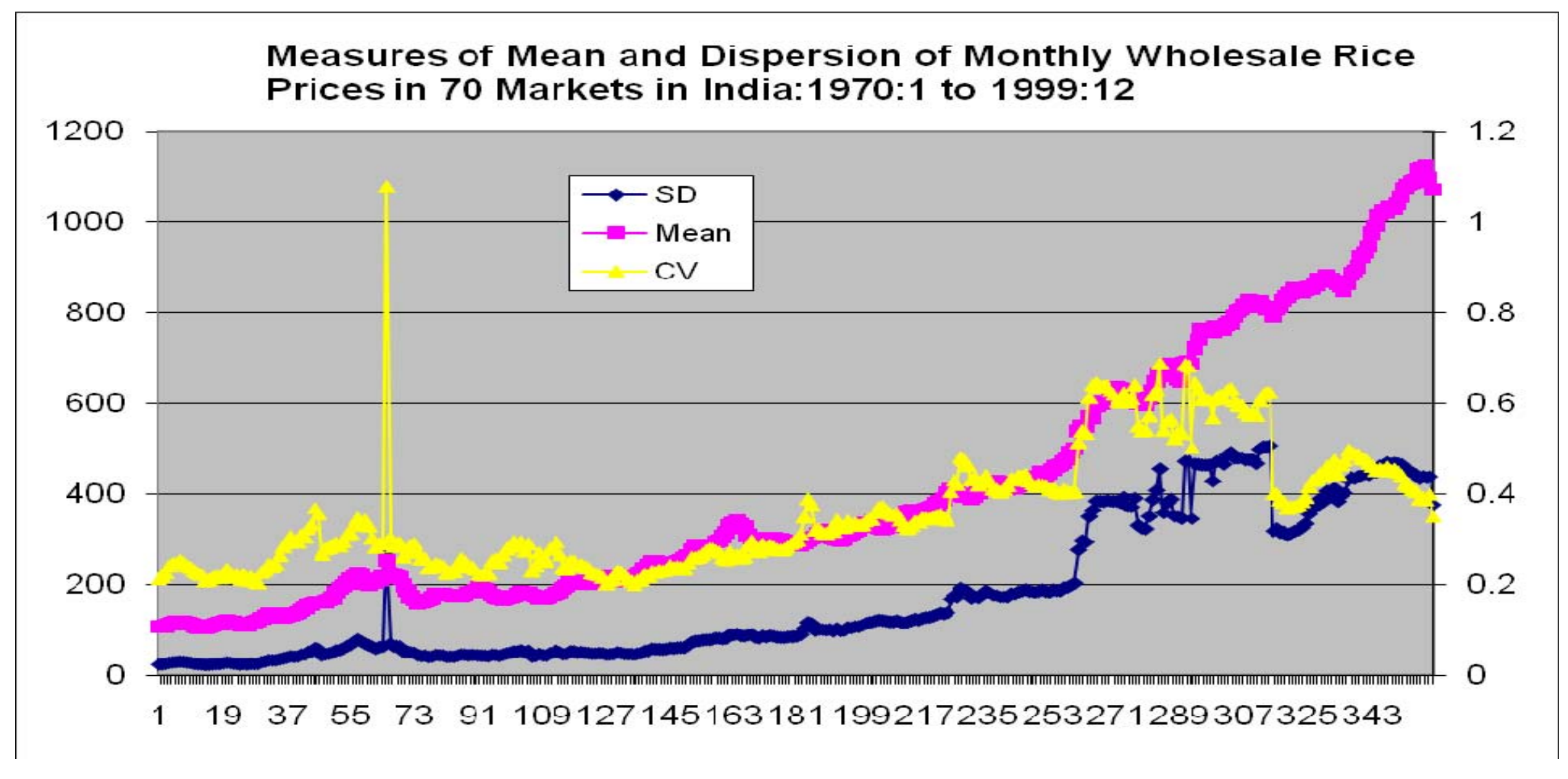

Figure 1: Measures of Mean and Dispersion of Monthly Wholesale Rice Prices in 70 markets in India: 1970:1 to 1999:12. (Horizontal axis refers to elapsed months since 1970:1. 
Table 1: Rate of growth at factor cost at 1999-2000 prices (per cent)

\begin{tabular}{|l|c|c|c|c|c|c|}
\hline & $\begin{array}{c}2000-01 \text { to } \\
2007-08 \\
\text { average }\end{array}$ & $2005-06$ & $2006-07$ & $2007-08$ & $2008-09$ & $2009-10$ \\
\hline Agriculture, Forestry and Fishing & 2.9 & 5.2 & 3.7 & 4.7 & 1.6 & -0.2 \\
\hline Mining and Quarrying & 4.9 & 1.3 & 8.7 & 3.9 & 1.6 & 8.7 \\
\hline Manufacturing & 7.8 & 9.6 & 14.9 & 10.3 & 3.2 & 8.9 \\
\hline Electricity, Gas and Water Supply & 4.8 & 6.6 & 10.0 & 8.5 & 3.9 & 8.2 \\
\hline Construction & 10.6 & 12.4 & 10.6 & 10.0 & 5.9 & 6.5 \\
\hline Trade, Hotels and Restaurants & $10.3^{a}$ & 12.4 & 11.2 & 9.5 & 5.3 & 8.3 \\
\hline Transport, Storage and Communication & & 11.5 & 12.6 & 13.0 & 11.6 & \\
\hline $\begin{array}{l}\text { Financing, Insurance, Real Estate and Business } \\
\text { Services }\end{array}$ & 8.8 & 12.8 & 14.5 & 13.2 & 10.1 & 9.9 \\
\hline Community, Social and Personal Services & 5.8 & 7.6 & 2.6 & 6.7 & 13.9 & 8.2 \\
\hline GDP at Factor Cost & 7.3 & 9.5 & 9.7 & 9.2 & 6.7 & 7.2 \\
\hline
\end{tabular}

N.B. $a=$ This refers to Trade, Hotels, Restaurants, Transport, Storage \& Communication

Source: Economic Survey, Ministry of Finance, Government of India, 2009-10.

Table 2 : Economic Growth and Poverty Reduction in Select Asian Countries (1995-2005)

\begin{tabular}{|l|c|c|c|}
\hline Country & $\begin{array}{c}\text { Average annual growth } \\
\text { of per capita GDP }\end{array}$ & $\begin{array}{c}\text { Annual rate of poverty } \\
\text { reduction (PPP \$0.75 a } \\
\text { day ultra poverty line) }\end{array}$ & $\begin{array}{c}\text { Ratio of annual rate of } \\
\text { poverty reduction to annual } \\
\text { per capita GDP growth rate }\end{array}$ \\
\hline India & $4.9 \%$ & $-26 \%$ & -0.5 \\
\hline Bangladesh & $3.7 \%$ & $-3.9 \%$ & -1.1 \\
\hline Sri Lanka & $3.4 \%$ & $-10.3 \%$ & -3.1 \\
\hline Viet Nam & $6.2 \%$ & $-13.5 \%$ & -2.2 \\
\hline
\end{tabular}

Source: IFPRI 2010 
Table 3: Comparable Estimates of Poverty and Inequality — All India

\begin{tabular}{|c|c|c|c|c|c|c|c|c|c|c|c|c|c|c|c|c|}
\hline & \multicolumn{16}{|c|}{ Rural } \\
\hline & \multicolumn{4}{|c|}{$\begin{array}{c}\text { Head Count ratio (per cent HCR) } \\
\text { Uniform } 30 \text { day rule (using official poverty lines) }\end{array}$} & \multicolumn{4}{|c|}{$\begin{array}{c}\text { Poverty Gap } \\
\text { using official poverty lines }\end{array}$} & \multicolumn{4}{|c|}{$\begin{array}{l}\text { Squared Poverty Gap } \\
\text { using official poverty lines }\end{array}$} & \multicolumn{4}{|c|}{ Gini Coefficient } \\
\hline & 1983 & 1987-88 & $1993-94$ & $2004-05$ & 1983 & $1987-88$ & $1993-94$ & 2004-05 & 1983 & $1987-88$ & 1993-94 & 2004-05 & 1983 & $1987-88$ & 1993-94 & 2004-05 \\
\hline \multirow[t]{3}{*}{ All-India } & 46.5 & 39.0 & 37.2 & 28.7 & 12.36 & 9.29 & 8.5 & 5.8 & 4.87 & 3.23 & 2.84 & 1.76 & 30.4 & 29.9 & 28.6 & 30.5 \\
\hline & \multicolumn{16}{|c|}{ Urban } \\
\hline & \multicolumn{4}{|c|}{$\begin{array}{c}\text { Head Count ratio (per cent HCR) } \\
\text { Uniform } 30 \text { day rule (using official poverty lines) }\end{array}$} & \multicolumn{4}{|c|}{$\begin{array}{c}\text { Poverty Gap } \\
\text { using official poverty lines }\end{array}$} & \multicolumn{4}{|c|}{$\begin{array}{l}\text { Squared Poverty Gap } \\
\text { using official poverty lines }\end{array}$} & \multicolumn{4}{|c|}{ Gini Coefficient } \\
\hline All-India & 1983 & 1987-88 & $1993-94$ & $2004-05$ & 1983 & 1987-88 & $1993-94$ & $2004-05$ & 1983 & 1987-88 & 1993-94 & 2004-05 & 1983 & 1987-88 & 1993-94 & 2004-05 \\
\hline & 43.6 & 38.7 & 32.6 & 25.9 & 11.4 & 10.2 & 8.0 & 6.2 & 4.4 & 3.8 & 2.9 & 2.0 & 33.9 & 35.0 & 34.4 & 37.6 \\
\hline
\end{tabular}

Source: Adapted from Himanshu (2007)

Note: The figures in Table 3 are computed using calorie-based poverty lines. Recently the Tandulkar Committee Report has argued in favour of augmenting these poverty lines by adding essential expenditures on health and education. As expected poverty rates are higher using these measures. 
Table 4: Demand Function for Calories with Interactions in Rural India, Pooled (1993-2004)

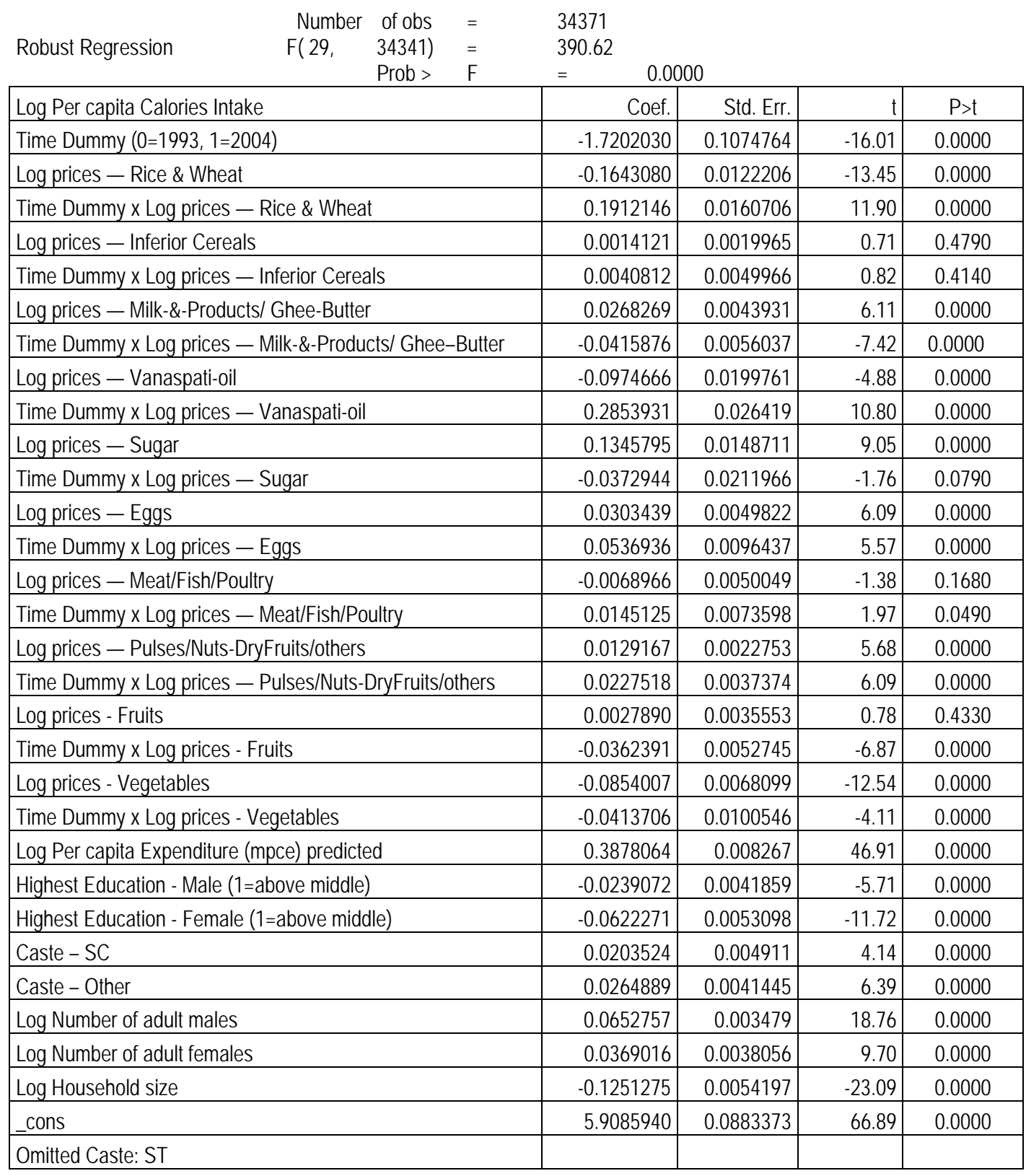

Source: Gaiha, Jha and Kulkarni (2010 b) 
Table 5: Demand Function for Calories with Interactions in urban India, Pooled (1993-2004)

Robust regression

$\begin{array}{lll}\text { Number of obs } & & 24803 \\ \mathrm{~F}(29,24773) & = & 409.12 \\ \text { Prob }>\mathrm{F} & = & 0.0000\end{array}$

\begin{tabular}{|c|c|c|c|c|}
\hline Log Per capita Calories Intake & Coef. & Std. Err. & $\mathrm{t}$ & $\mathrm{P}>\mathrm{t}$ \\
\hline Time Dummy $(0=1993,1=2004)$ & -0.9195787 & 0.1190358 & -7.73 & 0.0000 \\
\hline Log prices - Rice \& Wheat & -0.0507352 & 0.0132674 & -3.82 & 0.0000 \\
\hline Time Dummy $x$ Log prices - Rice \& Wheat & -0.0364669 & 0.0182183 & -2.00 & 0.0450 \\
\hline Log prices - Inferior Cereals & -0.0028333 & 0.0018964 & -1.49 & 0.1350 \\
\hline Time Dummy x Log prices - Inferior Cereals & -0.0037751 & 0.0047698 & -0.79 & 0.4290 \\
\hline Log prices - Milk - \& - Products/ Ghee - Butter & 0.0229197 & 0.0058593 & 3.91 & 0.0000 \\
\hline $\begin{array}{l}\text { Time Dummy x Log prices - Milk \& Products/ } \\
\text { Ghee-Butter }\end{array}$ & -0.0234831 & 0.0092065 & -2.55 & 0.0110 \\
\hline Log prices - Vanaspati - oil & -0.0096175 & 0.0229671 & -0.42 & 0.6750 \\
\hline Time Dummy x Log prices - Vanaspati-oil & 0.2258828 & 0.0301314 & 7.50 & 0.0000 \\
\hline Log prices - Sugar & 0.1074968 & 0.018126 & 5.93 & 0.0000 \\
\hline Time Dummy x Log prices - Sugar & -0.0839290 & 0.02589 & -3.24 & 0.0010 \\
\hline Log prices - Eggs & 0.0338505 & 0.0073154 & 4.63 & 0.0000 \\
\hline Time Dummy x Log prices - Eggs & 0.1050475 & 0.0150977 & 6.96 & 0.0000 \\
\hline Log prices - Meat/Fish/Poultry & 0.0001105 & 0.005595 & 0.02 & 0.9840 \\
\hline Time Dummy x Log prices - Meat/Fish/Poultry & 0.0073838 & 0.008409 & 0.88 & 0.3800 \\
\hline Log prices - Pulses/Nuts - DryFruits/others & 0.0142654 & 0.00324 & 4.40 & 0.0000 \\
\hline Time Dummy x Log prices - Pulses/Nuts -DryFruits/others & 0.0035167 & 0.0050589 & 0.70 & 0.4870 \\
\hline Log prices - Fruits & -0.0074601 & 0.0048532 & -1.54 & 0.1240 \\
\hline Time Dummy x Log prices - Fruits & -0.0309567 & 0.007751 & -3.99 & 0.0000 \\
\hline Log prices - Vegetables & -0.0379003 & 0.0076518 & -4.95 & 0.0000 \\
\hline Time Dummy x Log prices - Vegetables & -0.0788958 & 0.0122692 & -6.43 & 0.0000 \\
\hline Log Per capita Expenditure (mpce) predicted & 0.2820716 & 0.0117622 & 23.98 & 0.0000 \\
\hline Highest Education — Male (1=above middle) & -0.0075396 & 0.0055565 & -1.36 & 0.1750 \\
\hline Highest Education — Female (1=above middle) & -0.0272972 & 0.0057865 & -4.72 & 0.0000 \\
\hline Caste - SC & -0.0056799 & 0.0083835 & -0.68 & 0.4980 \\
\hline Caste - Other & -0.0082267 & 0.0071583 & -1.15 & 0.2500 \\
\hline Log Number of adult males & 0.0835158 & 0.0038817 & 21.52 & 0.0000 \\
\hline Log Number of adult females & 0.0420094 & 0.0041871 & 10.03 & 0.0000 \\
\hline Log Household size & -0.1933290 & 0.0088469 & -21.85 & 0.0000 \\
\hline _cons & 5.9775790 & 0.1175861 & 50.84 & 0.0000 \\
\hline Omitted Caste: ST & & & & \\
\hline
\end{tabular}

Source: Gaiha, Jha and Kulkarni (2010 b) 